\title{
Evaluation of electrophoretic profile and albumin quota in the cerebrospinal fluid of dogs with distemper showing or not neurvous signs
}

\author{
[Avaliação do perfil eletroforético e da cota de albumina do líquido cerebrospinal de cães \\ acometidos pela cinomose apresentando ou não sinais neurológicos] \\ F.G.V. Gama ${ }^{1}$, C.T. Nishimori ${ }^{1}$, M.R. Sobreira ${ }^{2}$, A.E. Santana ${ }^{3}$ \\ ${ }^{1}$ Aluno de pós-graduação - FCAV-UNESP - Jaboticabal, SP \\ ${ }^{2}$ Faculdade Moura Lacerda - Ribeirão Preto, SP \\ ${ }^{3}$ Faculdade de Ciências Agrárias e Veterinárias - UNESP - Jaboticabal, SP
}

\begin{abstract}
The electrophoretic profile of cerebrospinal fluid proteins and albumin quota was studied in healthy dogs and dogs with distemper in either nervous or non-nervous phases. Cerebrospinal fluid (CSF) samples from $30 \mathrm{dogs}$ were collected by puncture of the cisterna magna. The total protein content, the albumin quota, and the electrophoretic fraction of CSF proteins in agarose gel plates were evaluated. Results were similar in healthy dogs and dogs with distemper and no nervous signs, but were significantly increased in the group of dogs with distemper showing nervous signs. The study of CSF protein profile proved useful and contributed significantly on the detection of central nervous system disorders and damages to the blood-brain barrier during the nervous phase of distemper.
\end{abstract}

Keywords: dog, canine distemper, cerebrospinal fluid, protein, electrophoresis

\section{RESUMO}

Estudaram-se o perfil eletroforético das proteínas liquóricas e a cota de albumina em cães sem e com cinomose na fase neurológica e não-neurológica. A punção da cisterna magna para a obtenção de amostras de liquor realizou-se em 30 cães. Analisaram-se teores de proteinas totais, cota de albumina e fracionamento eletroforético das proteínas liquóricas em gel de agarose. Os resultados foram semelhantes nos cães normais e nos cães com cinomose sem sinais neurológicos e significativamente elevados no grupo de cães com cinomose apresentando sinais neurológicos. O estudo do quadro protéico do líquido cérebroespinhal foi útil e contribuiu significativamente na deteç̧ão de lesões ao sistema nervoso central e de danos à barreira hematoencefálica durante a fase neurológica da cinomose.

Palavras-chave: cão, cinomose, líquido cerebrospinal, proteina, eletroforese

\section{INTRODUCTION}

Cerebrospinal fluid (CSF) is produced by plasma ultrafiltration, based on active transport mechanisms through the blood-brain barrier. Experimental studies have shown that clinicians consider CSF analysis an access to the brain that is able to reflect physiopathological changes of the cerebral function. In order to obtain important information of diagnostic value, the CSF may be submitted to several tests used for blood and other biological fluids. The assessment of CSF proteins is of great value, since qualitative and quantitative changes of such proteins could be very important in the identification, follow up examination, and prognosis of central nervous system (CNS) diseases (Coles, 1986).

Recebido em 4 de julho de 2005

Aceito em 4 de dezembro de 2006

E-mail: fevelasque@yahoo.com.br

Apoio: FAPESP 
The level of protein of this fluid ranges from 12 to $40 \mathrm{mg} / \mathrm{dl}$, being much less than the plasma protein concentration (Coles, 1986; Braund, 1994). Such protein components are nearly exclusively represented by albumin, despite small amounts of globulins can be found (Braund, 1994). However, when CNS is damaged, the protein levels can increase in dogs with viral encephalitis (distemper), toxoplasmosis, bacterial meningitis, brain or spinal cord abscess, as well as in noninflammatory conditions, such as seizure states and uremia (Tudury et al., 1997). The increase in protein content might occur as a result of local production of protein in the central nervous system, although concurrent increase in total CSF albumin and in the ratio of CSF albumin to serum albumin (albumin quota) suggests impairment of the blood-brain barrier and leakage of plasma albumin, because it is solely produced by the liver (Delahunta, 1983; Feldman, 1989). Therefore, to differentiate both processes, it is mandatory to perform a CSF protein determination, including an electrophoretic analysis of proteins (Mcguirk and Macwilliams, 1992).

Among neurological diseases that afflict animals, distemper is considered the most common cause of encephalitis in dogs, leading to a high mortality rate or resulting in important sequelae that could compromise the animals' life quality (Greene, 1984; Chrisman, 1985). Having in mind that canine distemper could cause alteration of the CSF protein profile, and the need to add information concerning CSF protein changes in such disease, this research aimed at comparing CSF samples from healthy dogs and dogs with distemper showing or not neurological signs. The objective of this study was to measure CSF total proteins, to perform their electrophoretic fractioning in agarose gel, and to calculate the albumin quota to evaluate the damage in the blood-brain barrier in such animals.

\section{MATERIALS AND METHODS}

Thirty adult male and female mixed-breed dogs were enrolled in the study. For such, animals were assigned to one of three groups of $10 \mathrm{dogs}$ each: 10 healthy dogs were included in group 1 (G1); 10 dogs with distemper, with no history of previous vaccination against distemper virus, and presenting no nervous signs, but at least one of the following signs: serous or mucopurulent oculonasal discharge, bronchopneumonia, vomiting and diarrhea were included in group 2 (G2); another 10 dogs with distemper, with no history of previous shots against distemper virus, showing at least one of the following nervous signs: seizures, ataxia, myoclonus, hypermetric gait, dementia or circling, and nystagmus were included in group 3 (G3). All CSF samples were collected from owned animals presented for clinical evaluation.

The animals were chosen for groups 2 and 3 based on physical examination and ancillary tests - count blood cells (CBC) and serum biochemical profile -, including serology for canine distemper using a Dot-elisa commercial kit $^{1}$. After tranquilization with levomepromazine ${ }^{2}$, general anesthesia was induced and maintained with propofol $^{3}$, and cisternal puncture was carried out with a disposable 21-gauge, 1-inch needle, for cerebrospinal fluid collection. Following collection, the CSF sample was transferred to a glass vial.

The total protein and albumin content of the CSF and serum, was determined using the commercial $\mathrm{kit}^{4}$ "Sensi Prot" and albumin, respectively, which were read using a biochemical analyzer ${ }^{4}$. To allow electrophoretic separation, CSF samples were centrifuged ${ }^{5}$, at $12.000 \mathrm{~g}$ for 15 minutes, aided by the microconcentrator 0.5 $30.000 \mathrm{NMWL}^{6}$. Three $\mu \mathrm{l}$ of the concentrated CSF were subsequently placed in wells in agarose gel plates ${ }^{7}$, which were processed for 35 minutes at 90 volts. Gels were stained with amido black and were cleared by use of $5 \%$ acetic acid. Quantification of major protein fractions was accomplished by densitometry ${ }^{7}$, which allowed determining the relative values of albumin, $\alpha, \beta$, and $\gamma$-globulin fractions, and permitted to calculate the respective absolute values based on the percentage of each fraction. Albumin quota was obtained by the ratio of CSF albumin to serum albumin. Results were submitted to the Kruskal-Wallis test. When

\footnotetext{
${ }^{1}$ ImunoComb ${ }^{\circledR}$, Biogal - São Paulo, Brazil.

${ }^{2}$ Rhodia Farma - São Paulo, Brazil.

${ }^{3}$ Cristália - São Paulo, Brazil.

${ }^{4}$ Labtest Diagnóstica - Lagoa Santa, Brazil

${ }^{5}$ Eppendorf Laboratory Centrifuges - Hamburg, Germany

${ }^{6}$ Ultrafree, Millipore - MA, USA

${ }^{7}$ Celm - São Paulo, Brazil
} 
means were determined to be significant, they further underwent the Student-Newman-Keuls multiple comparison test at a significance level of $5 \%$.

\section{RESULTS}

The data obtained for total protein, albumin, albumin quota, and CSF gamma globulins
(Table 1) were similar between animals of groups 1 and 2. However, both groups significantly differed from group 3, which had increased protein levels. Although the analysis of alpha and beta globulins indicated nearness of results between $\mathrm{G} 1$ and $\mathrm{G} 2$, and much higher values for G3, statistical assessment disclosed significant differences among all groups.

Table 1. Mean and standard deviation $(\mathrm{X} \pm \mathrm{S})$ obtained for total protein (TP), albumin, $\alpha, \beta, \gamma$-globulins, and albumin quota of the cerebrospinal fluid from healthy dogs (control G1), and dogs with distemper showing (G3) or not (G2) nervous signs

\begin{tabular}{lcccccc}
\hline Group & $\begin{array}{c}\text { TP } \\
(\mathrm{mg} / \mathrm{dl})\end{array}$ & $\begin{array}{c}\text { Albumin } \\
(\mathrm{mg} / \mathrm{dl})\end{array}$ & Albumin quota & $\begin{array}{c}\alpha \\
(\mathrm{mg} / \mathrm{dl})\end{array}$ & $\begin{array}{c}\beta \\
(\mathrm{mg} / \mathrm{dl})\end{array}$ & $\begin{array}{c}\gamma \\
(\mathrm{mg} / \mathrm{dl})\end{array}$ \\
\hline G. 1 & $26.0 \pm 4.88 \mathrm{a}$ & $7.92 \pm 1.56 \mathrm{a}$ & $0.37 \pm 0.27 \mathrm{a}$ & $5.38 \pm 3.35 \mathrm{a}$ & $5.15 \pm 2.48 \mathrm{a}$ & $7.55 \pm 5.45 \mathrm{a}$ \\
G. 2 & $37.5 \pm 6.89 \mathrm{a}$ & $10.38 \pm 2.47 \mathrm{a}$ & $0.51 \pm 0.31 \mathrm{a}$ & $10.67 \pm 6.96 \mathrm{~b}$ & $6.89 \pm 2.65 \mathrm{~b}$ & $8.98 \pm 6.67 \mathrm{a}$ \\
G. 3 & $192.9 \pm 45.75 \mathrm{~b}$ & $68.33 \pm 17.37 \mathrm{~b}$ & $6.20 \pm 3.92 \mathrm{~b}$ & $40.52 \pm 28.82 \mathrm{c}$ & $43.81 \pm 33.03 \mathrm{c}$ & $40.19 \pm 40.99 \mathrm{~b}$ \\
\hline
\end{tabular}

Means followed by different letters in the colunun differ (Kruskal-Wallis and the SNK tests $(\mathrm{P}<0.05)$.

\section{DISCUSSION}

The results obtained in the assay of CSF total protein content of G1 and G2 animals were within the normal range described by Wright (1978), Bailey and Higgins (1985) and Oliver and Lorenz (1997). In the dogs of G3, it was observed a significant increase in CSF protein, according to several studies of viral neurological diseases (Safarty et al., 1986; Sorjonem, 1987; Abate et al. 1998). Furthermore, the mean values of total protein from animals of group were greater than those previously reported by Feitosa et al. (1997) in dogs with distemper in the nervous phase.

The CSF protein assessment in this study showed that albumin level was not statistically different between G1 and G2. Moreover, the results from both groups were within the reference range (Krakowka et al., 1987; Sorjonem, 1987). The albumin fraction reported for these groups corresponds to nearly $30 \%$ of CSF total protein, which was also observed by Sorjonem (1987) and Abate et al. (1998). However, it did not confirm a preceding investigation of Mayhew and Beal (1980), which showed that normal cerebrospinal fluid protein is composed almost entirely of albumin. For the animals included in G3, significantly higher levels of albumin were determined when compared with the other studied groups. Such results are in agreement with Sorjonen (1987), Sorjonen et al. (1989) and
Thomas et al. (1993), suggesting damage to the blood-brain barrier, due to the CNS infection by distemper virus, as a possible cause of increased CSF albumin. On the contrary, the dysfunction of the blood-brain barrier determined for G3 was not in agreement with previous findings in dogs with distemper (Sorjonen, 1987), in which only a mild disruption of the blood-brain barrier was seen. Groups 1 and 2 presented similar results for albumin quota, although values were a little above the normal range reported for dogs (Sorjonen, 1987).

The mean values of alpha and beta-globulin fractions were similar for animals of $\mathrm{G} 1$ and $\mathrm{G} 2$, despite both groups differed significantly, and results were very close to the reference range for healthy dogs described by Sorjonen (1987). Animals from group 3 presented significantly higher values for these protein fractions in comparison with groups 1 and 2. Such result was different from that reported for dogs with distemper by the same author, whose CSF analysis revealed reduction of $\alpha$ and $\beta$-globulin fractions. It is likely that the elevation of these globulins occurred as a consequence of the damaged blood-brain barrier, allowing plasma proteins to leak into the cerebrospinal fluid.

In contrast with $\alpha$ and $\beta$-globulins, $\gamma$-globulins did not differ between G1 and G2. Also, this globulin had values a little higher than the normal range reported by Sorjonen (1987), 
Sorjonen et al. (1989) and Thomas et al. (1993). An increase in CSF $\gamma$-globulins was seen in dogs with distemper, which was also observed in this research for animals of G3, despite the levels of this globulin in this study were much higher than reports from many investigators (Cutler and Averill, 1969; Abate et al., 1998). The magnitude of the blood-brain barrier harm and $\gamma$-globulins transudation could be the explanation for the changes found in this study, but it deserves to emphasize the possibility of local production of immunoglobulins within the nervous system, or both concurrently. Unfortunately, the local production of proteins could not be characterized based on the available data.

\section{CONCLUSIONS}

The determination of CSF total protein concentration, as well as the protein profile could facilitate the detection of central nervous system disorders and possible damages to the bloodbrain barrier during the nervous phase of distemper. However, in the absence of nervous signs, the studied parameters do not contribute to the determination of early alterations that could aid in the diagnosis of such viral disease.

\section{REFERENCES}

ABATE, O.; BOLlo, E.; LOTTI, D. et al. Cytological, immunocytochemical and biochemical cerebrospinal fluid investigations in selected central nervous system disorders of dogs. J. Vet. Med., v.45, p.73-85, 1998.

BAILEY, C.S.; HIGGINS, R.J. Comparison of total white blood cell count and total protein content of lumbar and cisternal cerebrospinal fluid of health dogs. Am. J. Vet. Res., v.46, p.1162-1165, 1985.

BRAUND, K.G. Diagnostic techniques, In: BRAUND, K.G. Clinical syndromes in veterinary neurology. St Louis: Mosby, 1994. p.333-421.

CHRISMAN, C.L. Investigações auxiliares especiais, In: CHRISMAN, CL. Neurologia dos pequenos animais. São Paulo: Roca, 1985 p.63-96.

COLES, E.H. Cerebrospinal Fluid, In: COLES, E.H. Veterinary clinical pathology. Philadelphia: W.B.Saunders, 1986. p.267-278

CUTLER, R.W.P.; AVERILL, D.R. Cerebrospinal fluid gamma globulins in canine distemper encephalitis. Neurology, v.19, p.1111-1114, 1969.

DELAHUNTA, A. Inflammatory diseases of the central nervous system, In: DeLAHUNTA, A. Veterinary neuropatology. 2.ed. Philadelphia: W.B.Saunders, 1983 p. 261-270.
FEITOSA, M.M.; FEITOSA, F.L.F.; KOHAYAGAWA, A. et al. Avaliação física, citológica, conteúdo de proteínas e determinação qualitativa de globulinas do liquor de cães com encefalite por cinomose. Braz. J. Vet. Res. Anim. Sci., v.34, p.147-151, 1997.

FELDMAN, B.F. Cerebrospinal fluid, In: Kaneko, J.J. Clinical biochemistry of domestic animals. 4.ed. San Diego: Academic, 1989. p.835-865.

FERNANDES, W.R. Determinação dos valores liquóricos normais de glicose, proteína, globulina, uréia, creatina fosfoquinase (CK), aspartato aminotransferase (AST), leucócitos e da coloração, turbidez e coagubilidade em cães sadios. Braz. J. Vet. Res. Anim. Sci., v.27, p. 209-216, 1990.

GREENE, C.E. Infections of the central nervous system. In: GREENE, CE. Clinical microbiology and infectious diseases of the dog and cat. Philadelphia: W.B.Saunders, 1984 p.226241.

KRAKOWKA, S.; AXTHELM, M.K.; GORHAM, J.R. Effects of induced thrombocytopenia on viral invasion of the central nervous system in canine distemper virus infection. $J$. Comp. Pathol., v.97, p.441-450, 1987.

MAYHEW, I.G.; BEAL, C.R. Techniques of analysis of cerebrospinal fluid. Vet. Clin. N. Am.: Small Anim. Pract.,v.10, p.155-177, 1980.

MCGUIRK, S.M.; MACWILLIAMS, P.S. Cerebrospinal fluid, In: COWELL \& TYLER. Cytology and hematology of the horse. California: American Veterinary Publications, 1992. p.163-171.

OLIVER, J.E.; LORENZ, M.D. Confirming a diagnosis, In: OLIVER, J.E.; LORENZ, M.D. Handbook of veterinary neurology. 2.ed. Philadelphia: W.B Saunders, 1997. p.90104.

SAFARTY, D.; CARRILlO, J.M.; GREENLEE, P.G. Differential diagnosis of granulomatous meningoencephalomyelitis, distemper, and suppurative meningoencephalitis in the dog. J. Am. Vet. Med. Assoc., v.188, p.387-392, 1986 .

SORJONEM, D.C. Total protein, albumin quota, and electrophoretic patterns in cerebrospinal fluid of dogs with central nervous system disorders. Am. J. Vet. Res., v.48, p.301-305, 1987.

SORJONEM, D.C.; COX, N.R..; SWANGO, L.J. Electrophoretic determination of albumin and gammaglobulin concentrations in the cerebrospinal fluid of dogs with encephalomyelitis attributable to canine distemper virus infection: 13 cases (1980-87). J. Am. Vet. Med. Assoc., v.195, p.977-980, 1989.

THOMAS, W.B.; SORJONEM, D.C.; STEISS, J.E. A retrospective evaluation of 38 cases of canine distemper encephalomyelitis. J. Am. Anim. Hosp. Assoc., v.29, p.129133, 1993.

TUDURY, E.A.; ARIAS, M.V.B.; BRACARENSE, A.P.F.L. et al. Observações clínicas e laboratoriais em cães com cinomose nervosa. Cien. Rural., v.27, p.229-235, 1997.

WRIGHT, J.A. Evaluation of cerebrospinal fluid in the dog. Vet. Rec.,v.103, p.48-51, 1978. 